\title{
Effect of Taping Therapy on Primary Dysmenorrhea Severity and Premenstrual Syndrome in University Students
}

Soheila Rabiepour ${ }^{1}, \underline{\text { Seyran Khezri }}^{2}$

1. Associate professor, Reproductive Health Research Center, Urmia University of Medical Sciences, Urmia, Iran. ORCID ID: 0000-0001-8592-6467

2. MSc student of Midwifery Counseling, Nursing \& Midwifery Faculty, Urmia University of Medical Sciences, Urmia, Iran (Corresponding Author), Tel: +98-4444335574, Email: Seyran.khezri.m@ gmail.com, ORCID ID: 0000-0001-7722-7770

\begin{abstract}
Background and Aim: The aim of this study was to determine the effect of taping therapy on primary dysmenorrhea severity, premenstrual syndrome and its dimensions in Sardasht University students from 2018 to 2019.

Materials and Methods: In this experimental study 50 female students with moderate to severe dysmenorrhea and mild to moderate premenstrual syndrome were selected randomly and placed into control $(n=25)$ and intervention $(n=25)$ groups by blocking method. The intervention group used tape; the control group did not use anything but were attended in a free training class session. The questionnaires used in this study included demographic and menstrual characteristics questionnaire, visual analog scale questionnaire, premenstrual syndrome checklist and Moos menstrual distress questionnaire. Data obtained from these questionnaires were analyzed using descriptive statistics and independent t-test, paired t-test, chi-square test and ANCOVA.
\end{abstract}

Results: There was no statistically significant difference between the two groups in regard to the demographic characteristics $(\mathrm{P}<0.05)$. The mean scores of dysmenorrhea, menstrual distress questionnaires and its dimensions except for arousal, were not significantly different between the intervention and control groups before the intervention $(\mathrm{P}<0.05)$. Also, there was no significant difference between the groups in relation to the total scores of dysmenorrhea, menstrual distress questionnaires and its dimensions, except for severity of dysmenorrhea after the intervention $(\mathrm{P}<0.05)$. Results of ANCOVA after controlling the confounding variables, showed only a significant difference between the control and intervention groups in regard to the severity of dysmenorrhea $(\mathrm{P}<0.05)$.

Conclusion: The results of this study showed that taping therapy can be used as an effective non-pharmacological method in the treatment of dysmenorrhea.

Keywords: Dysmenorrhea, Premenstrual syndrome, Taping therapy, Experimental study Received: Aug 5, 2020 Accepted: Jan 12, 2021

How to cite the article: Soheila Rabiepour, Seyran Khezri. Effect of Taping Therapy on Primary Dysmenorrhea Severity and Premenstrual Syndrome in University Students.प̊́LJSKU 2021;26(6):124-138.

Copyright $@ 2018$ the Author (s). Published by Kurdistan University of Medical Sciences. This is an open access article distributed under the terms of the Creative Commons Attribution-Non Commercial License 4.0 (CCBYNC), where it is permissible to download, share, remix, transform, and buildup the work provided it is properly cited. The work cannot be used commercially without permission from the journal 


\section{تأثير تييينَ ترايى بر شدت ديسمنوره اوليه و سندرم يش ازيش قاعدىى در دانشجويان}

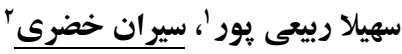

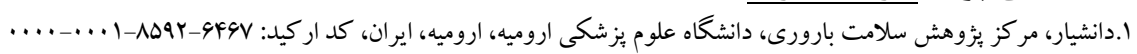

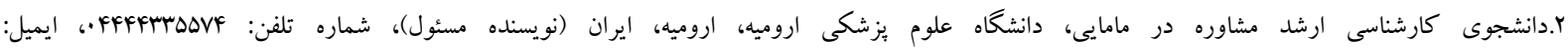

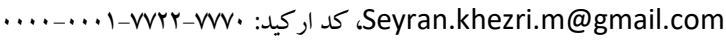

جكکبه

زمينه و هدف: هدف از مطالعه حاضر تعيين تأثير تييينك ترابى بر شدت ديسمنوره اوليه، سندرم بيش از قاعدگى و ابعاد آن در

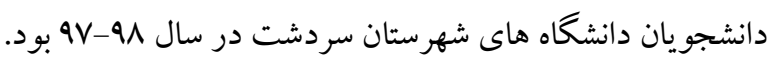
مواد و روشها: نمونه يزوهش اين مطالعه مداخلهاى شاهد دار، • ه دختر دانشجو با ديسمنوره ى متوسط تا شديد و همبجنين سندرم

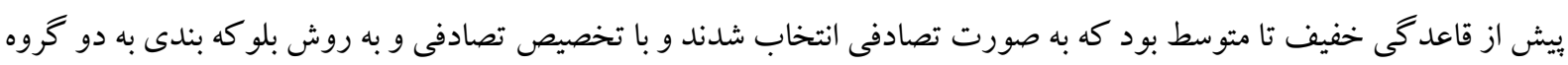

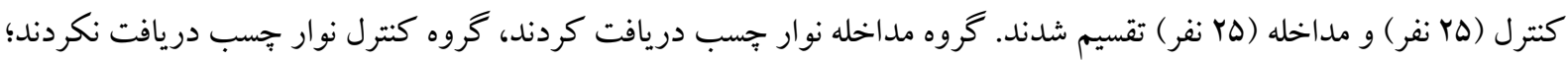

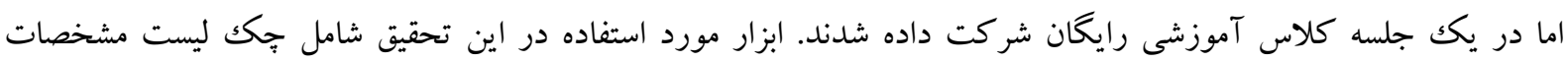

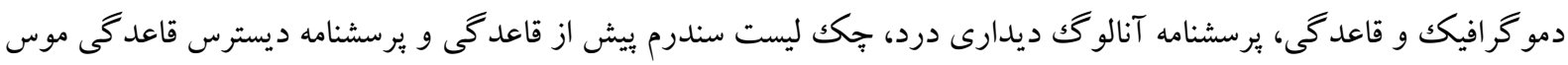

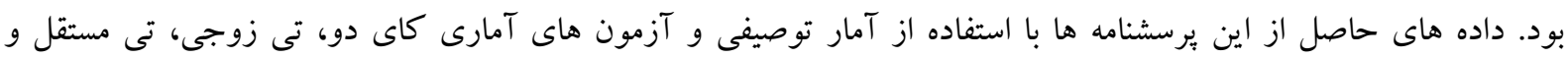
كوواريانس، مورد تجزيه و تحليل قرار گرفت.

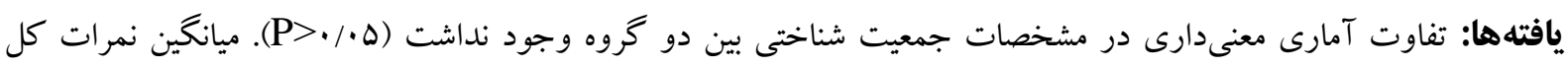

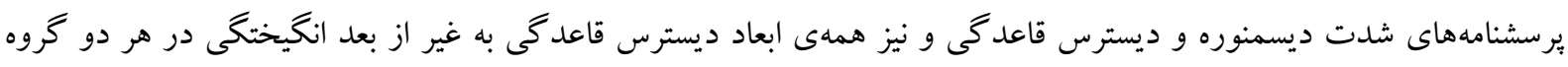

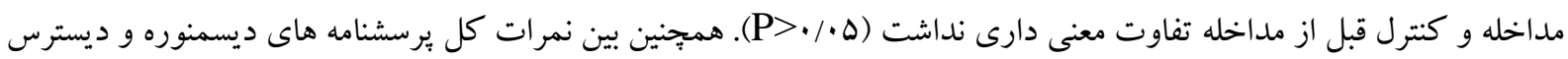

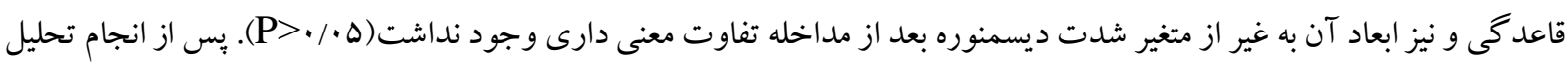

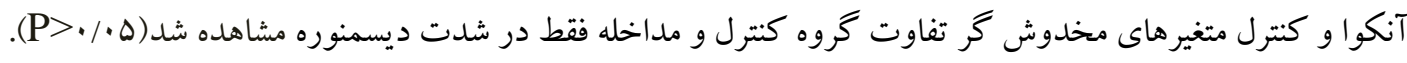

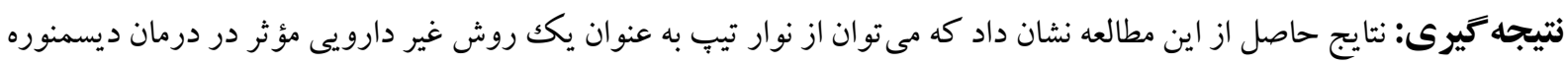
كلمات كليدى: ديسمنوره، سندرم يِيش از قاعدگىى، تيينگك ترابى، مطالعه مداخلهاى

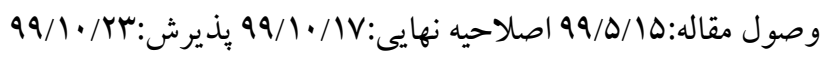


افتد(|f)، همجنين سندرم يِش از قاعدگى مى تواند با افزايش

خطر هيير تانسيون در آينده همر اه باشد(ها ). اكرجه ديسمنوره و سندرم بيش از قاعدگى در زمان هاى

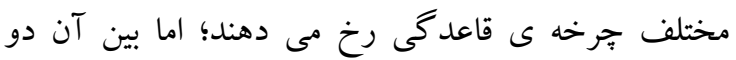

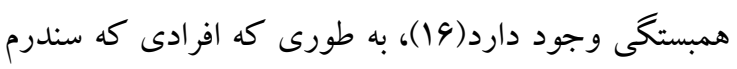
بيش از قاعدكى شديد را گزارش مى كنند، از ديسمنوره دارد نيز شكايت دارند(IV). در مطالعات مختلف بين شدت سند سندرم

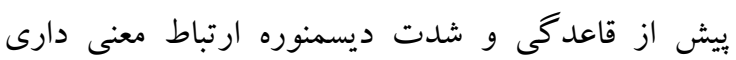

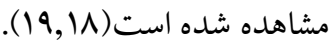

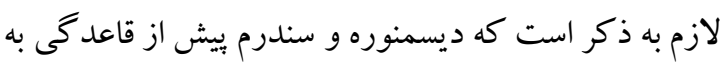
طور وسيعى بر روى كيفيت زندگى زنان و نيز فعاليتهاى

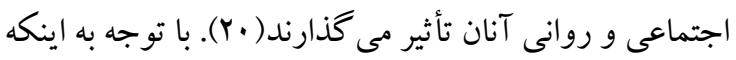

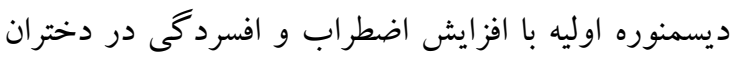
همراه است؛ بنابراين انتظار مىرود كاهش ديسمنوره بتواند باعث كاهش افسردگى و اضطراب وابسته به آن و درنتيجه كاهش سندرم ييش از قاعدگى گَردد( (Y). به دليل ناشناخته

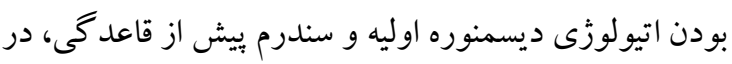
حال حاضر درمانى قطعى براى آنان وجود ندارد(YY). هر جرند شواهد يُزوهشى مبنى بر اثربخشى درمانهاى دارويى وجود

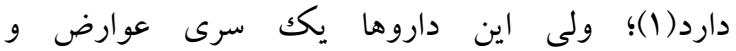
محدوديتهاى مصرف نيز دارند، از جمله اينكه برخى افراد با مداخلات دارويى تسكين نمىيابند و برخى نيز به دليل منع مصرف يا عوارض جانبى، از اين داروها استفاده نمى كنند.

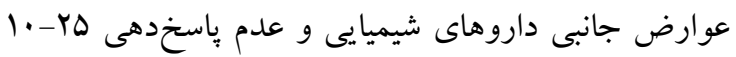
درصدى دردهاى قاعدگى به داروهاى مسكن منجر به كرايش بعضى از افراد به طب مكمل شده است(r (r). يكى از روشهاى طب مكمل تييينگ - ترايى ميباشد كه در سال 1999 توسط دكتر كنزو كيس ابداع گرديد و به همين دليل

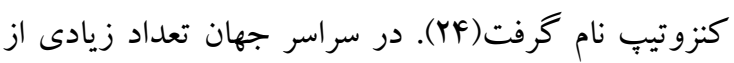

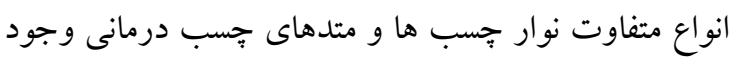
دارد. جون علل و علائم بيمارى ها اختصاصى هستند؛ بنابر اين روش هاى تييينگ نيز متنوع مى باشند(Y) (YD).

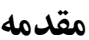

تعداد زيادى از زنان، از مشكلات مرتبط با قاعدگى رنج مىبرند كه قاعدگى دردناكك يا ديسمنوره و سندرم بيش از

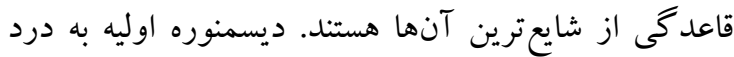

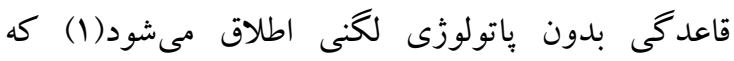

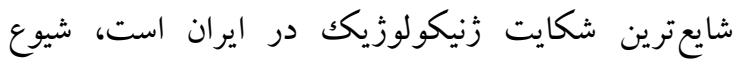
ديسمنوره اوليه در سطح جهان در مطالعات مختلف از و

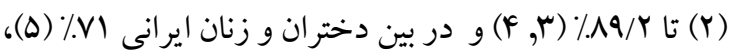

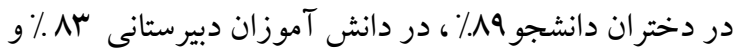

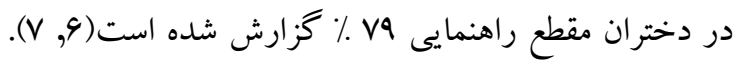
ديسمنوره باعث كيفيت بايين خواب شده و تأثيرات منفى بر درابي

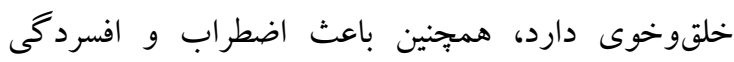
مى گردد(^). تحقيقات اخير نشان دادهاند كه ديسمنوره اوليه

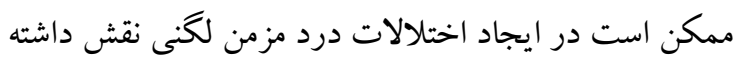
باشد(9, • (1)، به طورى كه سازمان بهداشت جهانى تخمين

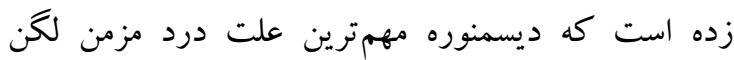

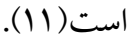

در سندرم بيش از قاعدگى بيمار در خلال بِنج روز قبل از

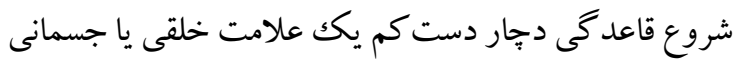

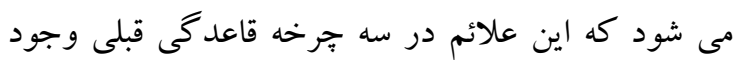

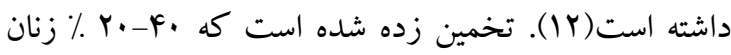

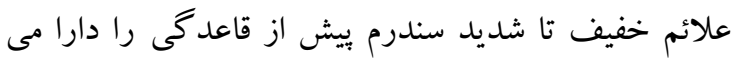
باشند، در حالى كه ^-r درصد زنان از اختلال ديسفوريكك بيش از قاعدكى (PMDD)، يكك فرم شديد سندرم بيش از قاعدگى كه به عنوان يك اختلال ديرسيو طبقه بندى شده است، رنج مى برند( II). در يكك مطالعه مئا آناليز در ايران

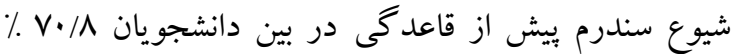
كزارش شده است(rا). سندرم ييش از قاعدگى منجر به مشكلات روانشناختى از قبيل اضطراب، افسردگى و حتى خود كشى مىشود. زنان مبتلا به سندرم ييش از قاعدگى بيشتر از زنان فاقد آن، در معرض خطر افسردگى مى باشند(A). اكثر

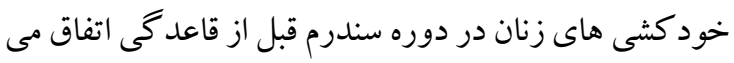


به طور همزمان مورد بررسى قرار مى دهد. درمان ديسمنوره و سندرم بيش از قاعدگى به دليل راجعه بودن و مختل كردن فعاليت هاى روزانه در هر ماه، هنوز محور تعداد زيادى از

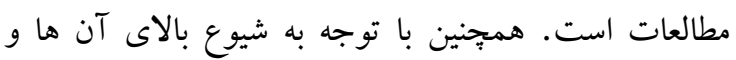

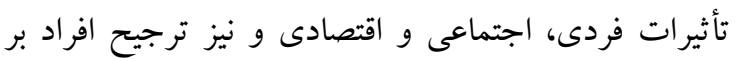
اساس مطالعات به استفاده از طب مكمل نسبت به درمانهاى

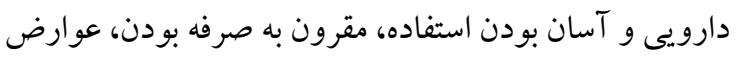
جانبى كم، در دسترس بودن و غير تهاجمى بودن تيبينك

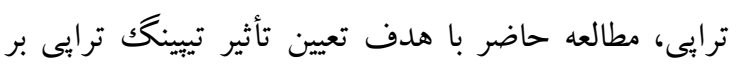

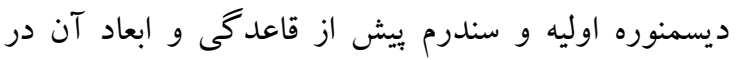

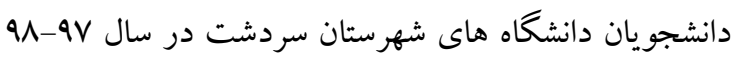

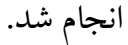

\section{مواد و روش ها}

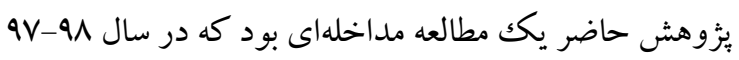
بر روى دانشجويان دختر دانشكاههاى شهرستان سردشت بـائ

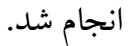
حجم نمونه و نمونه گيرى:

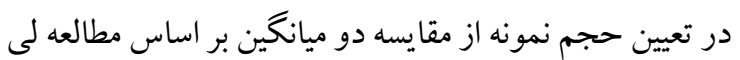

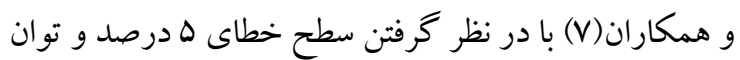
ه9 درصد، حجم نمونه اY نفر محاسبه شد. با در نظر گرفتن ريزش •r درصد، در هر گروه ها نفر وارد مطالعه شدند.

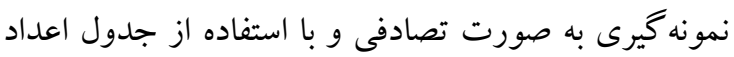
تصادفى انجام شد، تقسيم شر كت كنند گان به دو گروه كنترل و مداخله نيز به صورت تخصيص تصادفى و با روش بلو كه

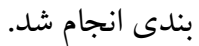
جهت تخصيص تصادفى rا بلوكى F تايى از تركيب هاى

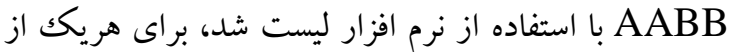
آنها يكك كد اختصاص داده شد و سبس به طور تصادفى يكك سو كور از اين كدها هr نفر براى هر گروه انتخاب شدند.

$$
\text { تعيين حجم نمونه: }
$$

انواع رايج تيينك، الاستيك(elastic) و غير

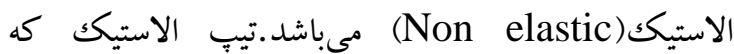
كينزيوتيب(Kenzo tape) نيز خوانده مى شود، در اشكال I Y, X,V,finger star تيبّ غير الاستيك به شكل مشبك و اسباير ال(spiral) وجود

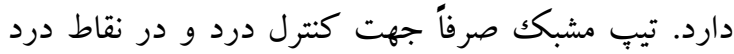
استفاده مى شود. نوع اسيايرال آن بيشتر در ارتويدى كاربرد

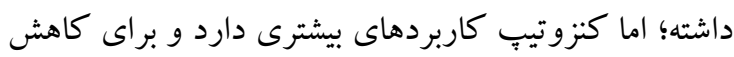
درد، تورم، ثابت كردن مفاصل و موارد ديخر كاربرد

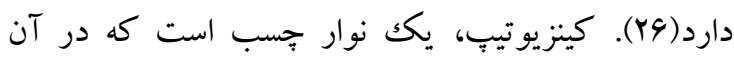

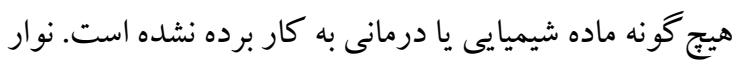

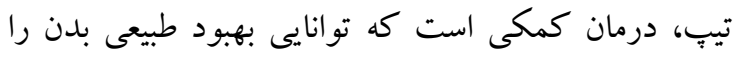
افزايش داده و تعادل بدن را بهوسيله تنظيم جريان الكترومغناطيسى يوست اصلاح مى كند و به طور غيرمستقيم

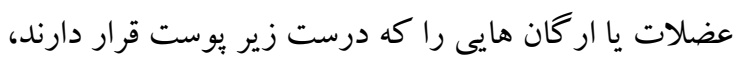
تحريك مى كند(9). گفته مى شود اين تكنيك سه عملكرد دارد: طبيعى كردن عملكرد عضلانى، افزايش جريان لنف و كردش خون، كاهش درد(YD). عوارض جانبى كينزيوتيٍ بسيار كم بوده و فقط واكنشهاى آلرزيكك يوستى گزارش شده است(YV) . اثرات تيبينگك در

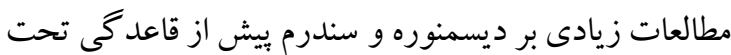
بررسى قرار گرفته است. در مطالعه ليم(9)، توماس(YN) و

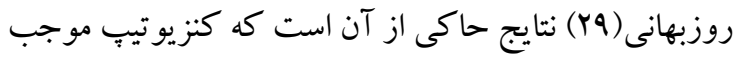

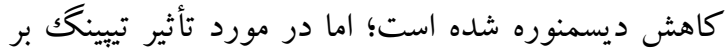
سندرم ييش از قاعدگى شواهد كافى وجود ندارد و نيازمند مطالعات بيشتر است. با توجه به اين كه مطالعات مختلف تأثير

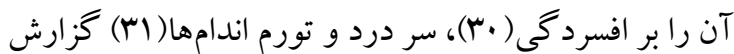
نموده اند و از طرفى وجود اين علائم مى تواند از علائم

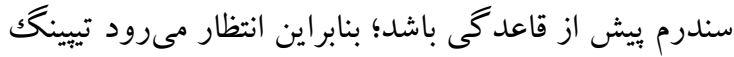

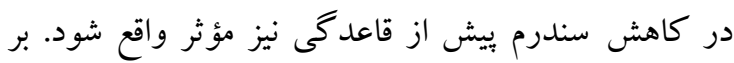

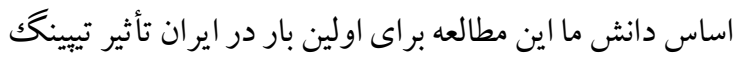

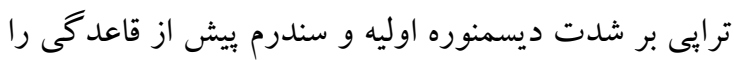


جكك ليست بررسى سندرم يِي از قاعدگى :

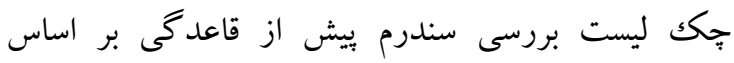

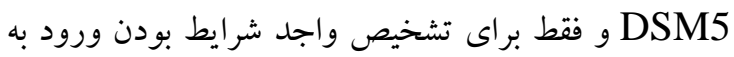

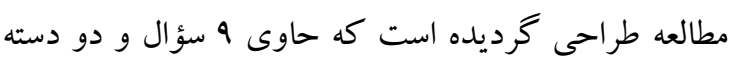

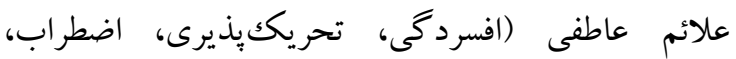

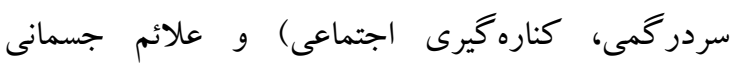
(حساسيت بستانها، نفخ غير طبيعى، سر درد، تورم اندامها)

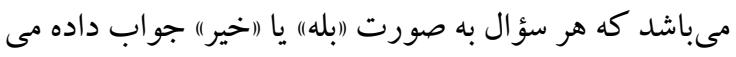

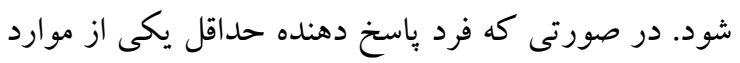

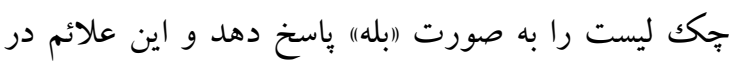
خلال ينج روز قبل از شروع قاعدگى شروع شده و در سه سيكل اخير وجود داشته باشد، تشخيص سندرم بيش از

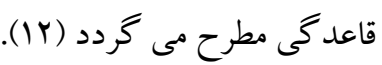
بر بشنامه ديسترس قاعدگى (MDQ) קرسشنامه ديسترس قاعدگىى، توسط رادوف موس در سال

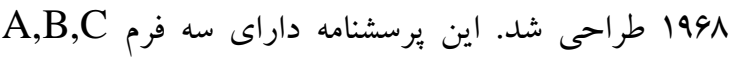

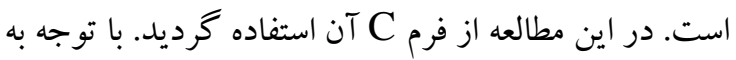
اين فرم از افراد خواسته شد هر يكك از علائم را با توجه به آخرين دوره قاعدكى ارزيابى كنند. اين برسشنامه شامل تركيبى از \&4 سؤال در 1 طبقه (r طبقه

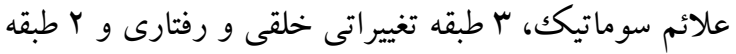
مربوط به خرده مقياس هاى اضافى) بوده و حاوى 9 سؤال در لرع

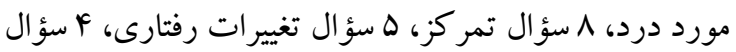
واكنشهاى اتونوميك،، F سؤال احتباس آب، 1 سؤال احساسات منفى، 9 سؤال كنترل و هـ سؤال انخيختخى است. از شر كت كنند گان خواسته شد هر يك از علائم را با توجه به آخرين دوره قاعدگى خود ارزيابى نمايند. اين كار از طريق

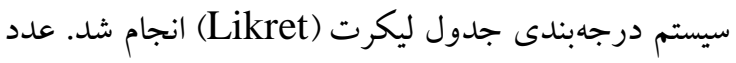

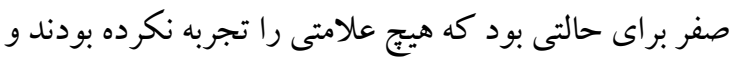

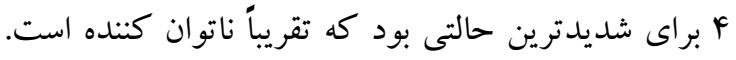
نمره صفر بيانگر عدم ديسترس،

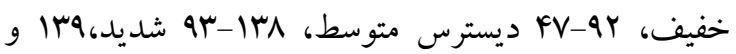

$$
\mathrm{n}=\frac{\left(\mathrm{Z}_{1-\alpha / 2}+\mathrm{Z}_{1-\beta}\right)^{2}\left(\mathrm{~S}_{1}^{2}+\mathrm{S}_{2}^{2}\right)}{\left(\mu_{1}-\mu_{2}\right)^{2}}
$$

$\frac{10.49 \times(815.67+.860 .83)}{873.79^{2}}=$

لازم به ذكر است كه طبق فلوجارت رسم شده كل دختران دانشجوى دانشكاههاى شهر سردشت سوح نفر بودند، با توجه

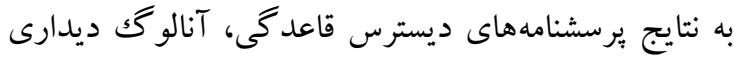

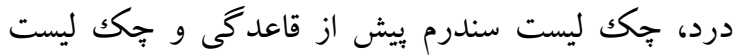
مشخصات عمومى و قاعدگى افراد، هو نفر واجد شركت در

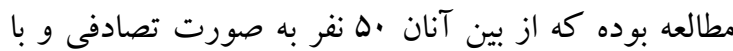
استفاده از جدول اعداد تصادفى انتخاب شده و بعد از اخذ

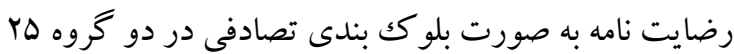
نفره كنترل و مداخله تخصيص يافتند. معيارهاى ورود به مطالعه شامل: محدودهى سنى ه广-1 ا ساله،

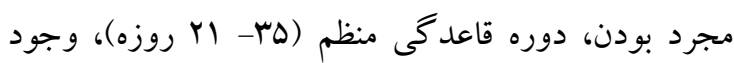

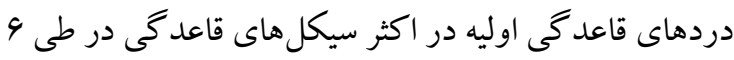

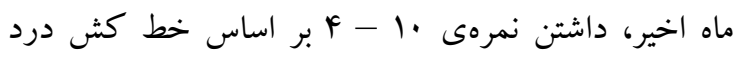

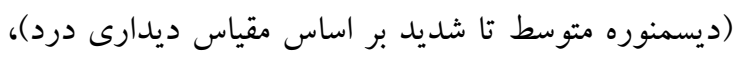
داشتن حداقل يكى از معيارهاى تشخيصى سندرم يِيش از

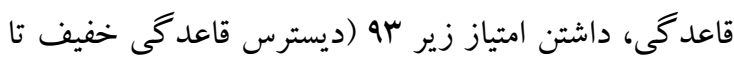

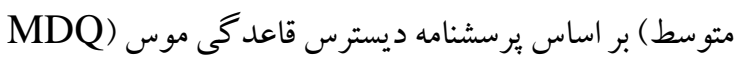

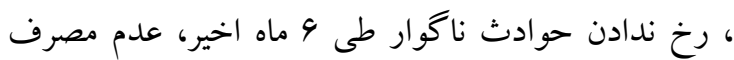

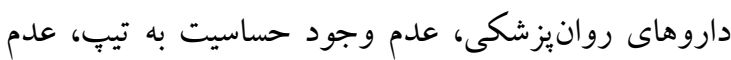
سابقهى سو ءمصرف الكل وعدم استعمال دخانيات بود. معيارهاى خروج از مطالعه نيز شامل: بروز هر گونه حساسيت نسبت به نوار جسب و عدم تمايل به ادامه همكارى فرد بود.

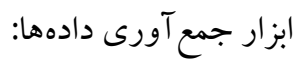
جكك ليست مشخصات عمومى و قاعدگى افر اد : اين جُك ليست شامل: سن، قد، وزن، سن منار ك؛، متوسط

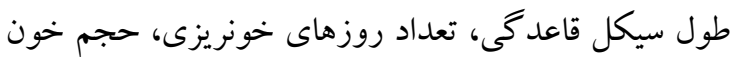

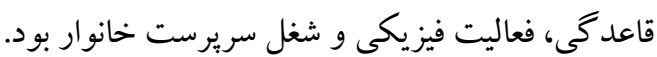


آتى، تكميل نمودند. از بين اين تعداد VV نفر داراى ديسمنوره خفيف، •و نفر متوسط و 1.r نفر داراى ديسمنوره شديد بودند. تعداد 199 نفر داراى ديسترس قاعدگى خفيف، $19 V$ نفر ديسترس متوسط و YF نفر داراى ديسترس شديد بودند؛

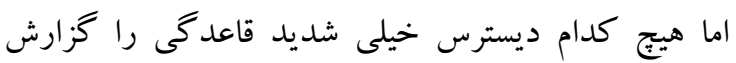

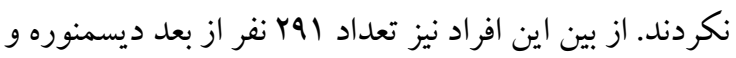

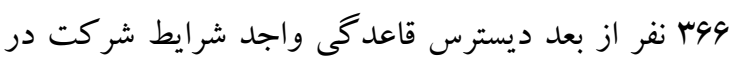

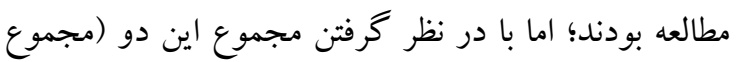

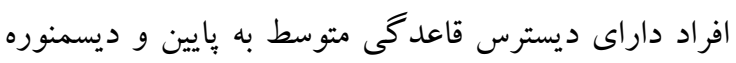
متوسط به بالا) و ساير معيارهاى ورود، فقط هُه نفر واجد

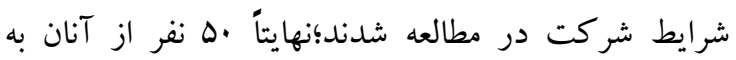
صورت تصادفى انتخاب و با روش بلوككبندى تصادفى به دو گروه كنترل و مداخله تخصيص يافتند. از هر كدام از اعضاى دو گروه، رضايت نامه كتبى آكاهانه اخذ شد، به آنها هدف مطالعه و احتمال تخصيص داده شدن به گروه مداخله يا كنترل توضيح داده شد. به كروه مداخله توضيحاتى در خصوص انجام كار و واله مدتزمان انجام مداخله داده شد و به تمامى سؤالات آنان

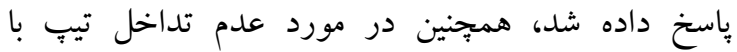
فعاليتهاى روزمره و عدم ممانعت استحمام در اين دوران با نإن توجه به استفاده از نوع ضد آب آن در اين مطالعه، توضيحات

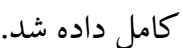

شر كت كنند كان به مدت ب سيكل بيخيرى شدند. در سيكل اول بر روى گروه مداخله تست حساسيت، با يكك تكه

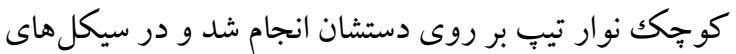

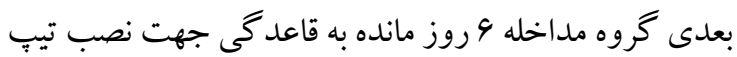

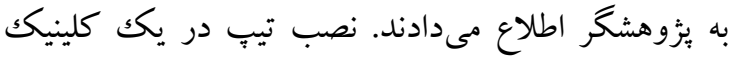

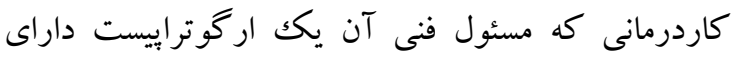

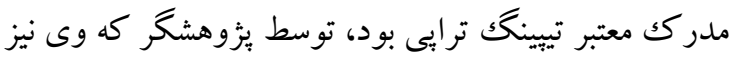

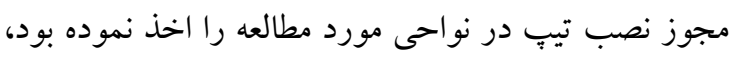

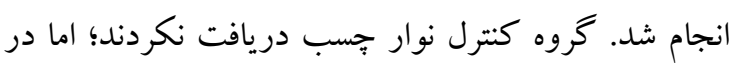

بالاتر نشان دهنده ديسترس خيلى شديد مى باشد(r).

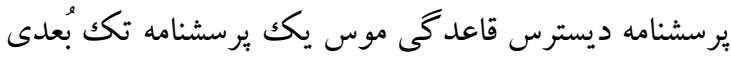

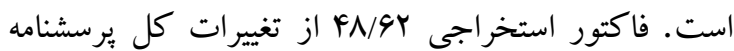
ديسترس قاعدگى موس را تأييد نمود. ِايايى يرسشنامه

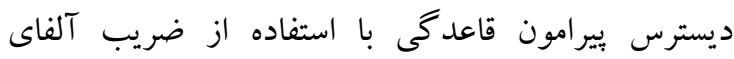

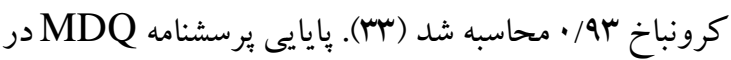
اين مطالعه با استفاده از ضريب آلفاى كرونباخ به/ • محاسبه

ير سُشنامه مقياس ديدارى درد (visual analog scale)

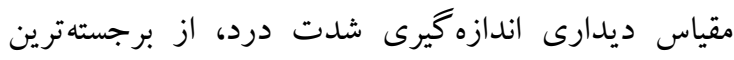

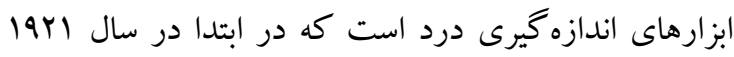
توسط هايس و ياترسون (Hise \& Patresone) ابداع شد. اين ابزار يكك خط كث •ا ل سانتىمترى است كه در انتهاى سمت جبٍ آن وازَه بدون درد و در انتهاى سمت راست آن وازه شديدترين حالت درد نوشته شده است. فرد با توجه به

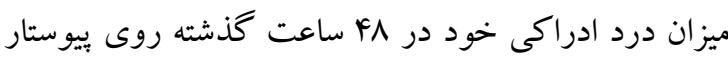

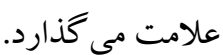
مقياس اندازهگيرى خطى _ ديدارى درد از صفر تا ده بدين صورت تقسيمبندى مى شود: ا--: بدون درد، ؟- "ז: درد

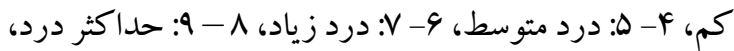
• (1: (1) درد غير قابل تحمل (YF).

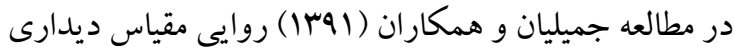
درد از طريق اعتبار محتوا و بايايى آن با استفاده از ضريب

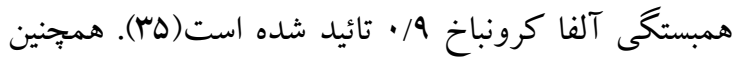

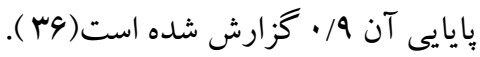

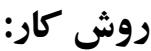
ابتدا تمامى لهوب دانشجوى دختر دانشگاههاى سردشت، با

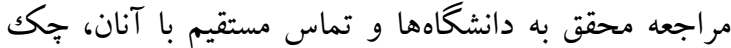
ليست سندرم ويش از قاعدگى، برسشناههاى آنالو گك ديدارى درد و ديسترس قاعدگى و جكك ليست مشخصات دمو گرافيك و قاعدگى را جهت تعيين افراد واجد شرايط شر كت در مطالعه و همجِين به عنوان بيش آزمون در منتخبين 
IR.UMSU.REC.1398.044 اخذ شد، همجنين يروتكل مطالعه نيز در سايت مداخلات بالينى ايران ثبت شده

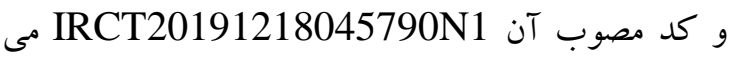
باشد. از هر كدام از نمونه ها رضايت آكاهانه براى شركت

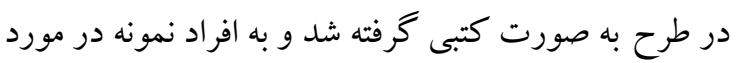
محر مانه بودن اطلاعات آنها اطمينان داده شد. همجِنين نمونه ها با كد مربوطه شناسايى شدند. آدرس و شماره تلفن مجرى در اختيار هر يكك از آنان قرار داده شد تا در صورت نياز و بروز هر گونه مشكل با ايشان تماس حاصل آيد. توضيحات

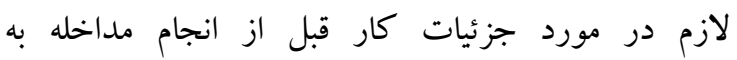

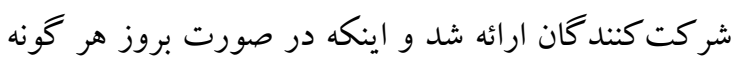
عارضه، مجرى موظف به برداخت هزينه درمان و نيز هماهنكى جهت ويزيت يز شكى و يا بسترى مى باشد. روش تحليل داده ها:

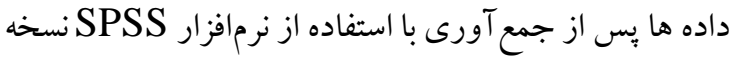
كT و آزمونهاى آمارى كاى دو، تى زوجى، تى مستقل و كوواريانس با سطح معنى دارى كمتر از هـ/• مورد تجزيه و تحليل قرار گرفت.

\section{يافتهها} ميانگين سنى دانشجويان در گروه مداخله I/

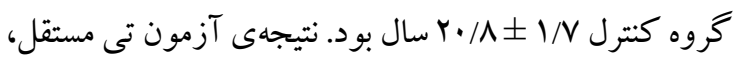
نشان داد كه تفاوت آمارى معنىدارى در مشخصات جمعيت

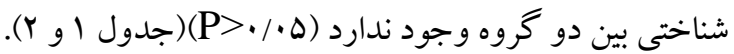

يك جلسه كلاس آموزشى رايگان در مورد بهداشت قاعدگى شر كت داده شدند و به سؤالات آنان باسخ داده شد.

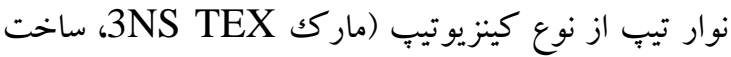

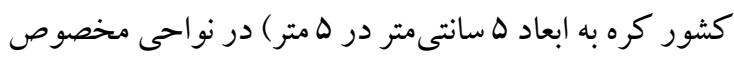

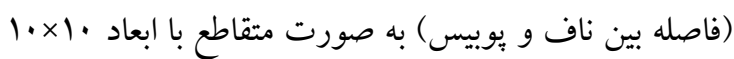

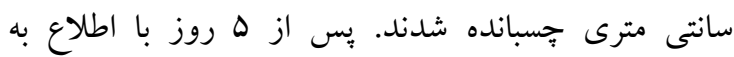

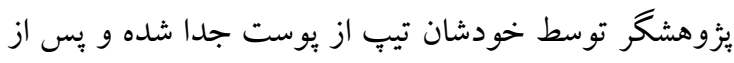

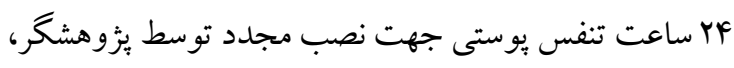
به كلينيك مراجعه كردند (شماره تلفن خودشان و يكى از از افراد درجه يكك هم خانهان گرفته شد و شماره تلفن

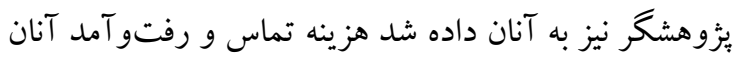
يرداخت شد). اين عمل به مدت · ا روز انجام شد. ه روز قبل

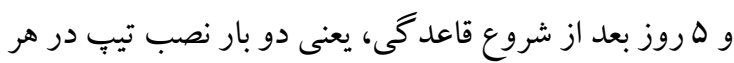

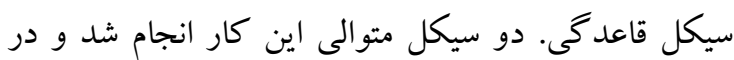

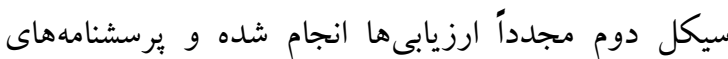

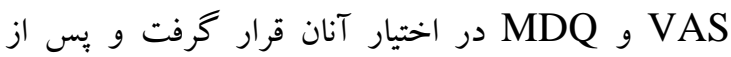
برداشتن تيٍ، ارزيابى با VAS و نيز با MDQ و

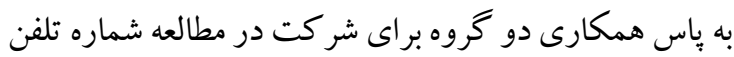
محقق در اختيار آنان قرار داده شد و در مواقع نياز به مشاوره

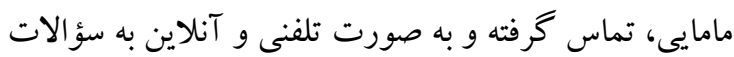

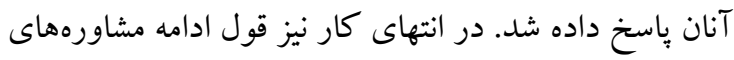
رايگان در آينده به شر كت كنند كان داده شد.

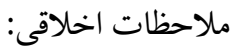
يرويوزال مطالعه حاضر در معاونت يُّوهشى دانشگاه علوم يزشكى اروميه تصويب شده و كد اخلاق با شماره

جدول ا. مقايسه مشخصات جمعيت شناختى كمى در دو كروه كنترل و مداخله

\begin{tabular}{|c|c|c|c|}
\hline P-value & 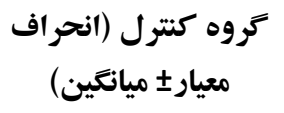 & 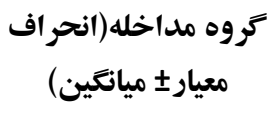 & متغير \\
\hline . A & $r \cdot / \Lambda \pm I / V$ & $r I / r \pm r / l$ & سن \\
\hline$\cdot / r$ & $1 / 9 \pm \cdot / \Delta r$ & $r / 1 \pm \cdot / 9$ & *BMI \\
\hline$\cdot / 9 r$ & $\mid F / Y \pm \cdot / 9$ & $|r /| \pm r / \mid$ & سن منار كى \\
\hline$\cdot / F T$ & $r V / F \pm r / q$ & $r N / I \pm r / l$ & طول سيكل قاعدگى \\
\hline
\end{tabular}

(body mass index) نمايه توده بدنى (bu )

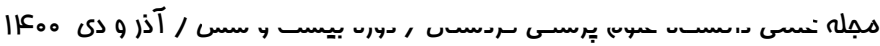




\begin{tabular}{|c|c|c|c|c|}
\hline نتيجه آزمون & 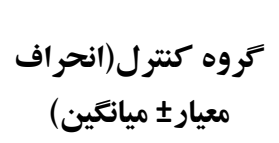 & 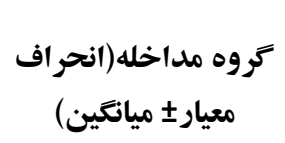 & & متغير \\
\hline \multirow{3}{*}{.194} & $\Lambda(/ / r Y)$ & $1 \cdot(/ / \% \cdot)$ & كم & \multirow{3}{*}{ حجم خون } \\
\hline & $9(\% / 4)$ & $9(\% / Y F)$ & متوسط & \\
\hline & $\Lambda(/ / r Y)$ & $9(\% / 4)$ & زياد ل & \\
\hline \multirow{3}{*}{$\cdot / \mathrm{V} 9$} & $M(\% / Y)$ & $\operatorname{lV}(\% .9 \Lambda)$ & آزاد & \multirow{3}{*}{ شغل سريرست } \\
\hline & $r(\% / \wedge)$ & $r(/ / \wedge)$ & كارمند & \\
\hline & $\Delta(\% / r \cdot)$ & $9(\% / Y F)$ & ساير & \\
\hline \multirow{3}{*}{$\cdot / 91$} & $9(\% / Y)$ & $\Delta(/ / r \cdot)$ & 1-1 روز & \multirow{3}{*}{ خداد روزهاى } \\
\hline & $M(/ V Y)$ & $19(\%$ V9) & r-r روز & \\
\hline & $1(\%)$ & $1(\% / F)$ & بيشتر از V روز & \\
\hline \multirow{5}{*}{$\cdot / \Delta r$} & $\Lambda(/ / r Y)$ & $9(/ / 49)$ & زير شكم & \multirow{5}{*}{ قاعدمتى از بدن در كه درد آن ناحيه } \\
\hline & $F(\% 19)$ & $1(\% / 4)$ & كمر & \\
\hline & $9(/ / 44)$ & $V(\% / \wedge)$ & زير شكم و كمر & \\
\hline & $1(\% / F)$ & $r(/ / \wedge)$ & زير شكم و ران & \\
\hline & $r(\% / r)$ & $4(\% / Y F)$ & ساير ساير & \\
\hline \multirow{3}{*}{$\cdot / f$} & $\mathbb{1 r}(/ . \Delta r)$ & $1 \cdot(\% / \cdot)$ & هر تز & \multirow{3}{*}{ فعاليت فيزيكى } \\
\hline & $11(\% F F)$ & $11(/ . F F)$ & 1-זبار در هفته & \\
\hline & $1(\% / F)$ & $F(\% 19)$ & r بار در هفته و بيشتر & \\
\hline
\end{tabular}

جدول r. مقايسه شدت ديسمنوره، ديسترس قاعد

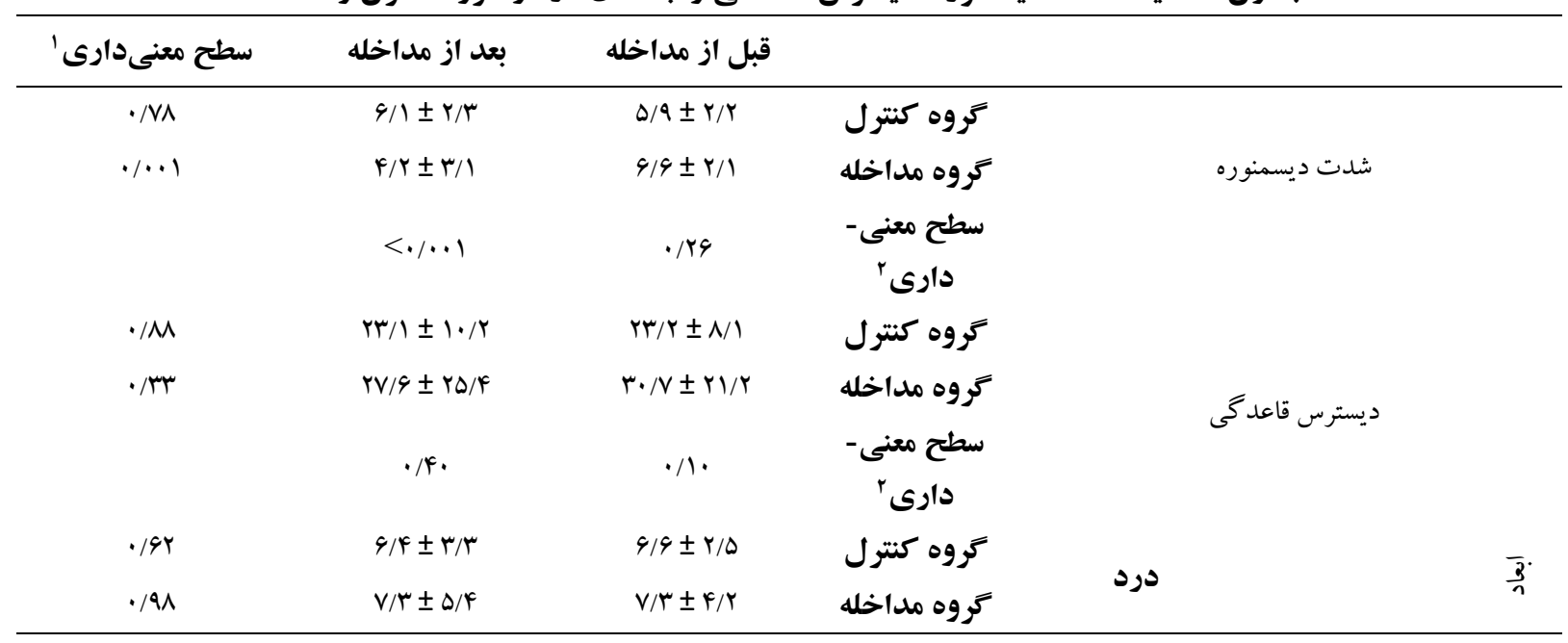




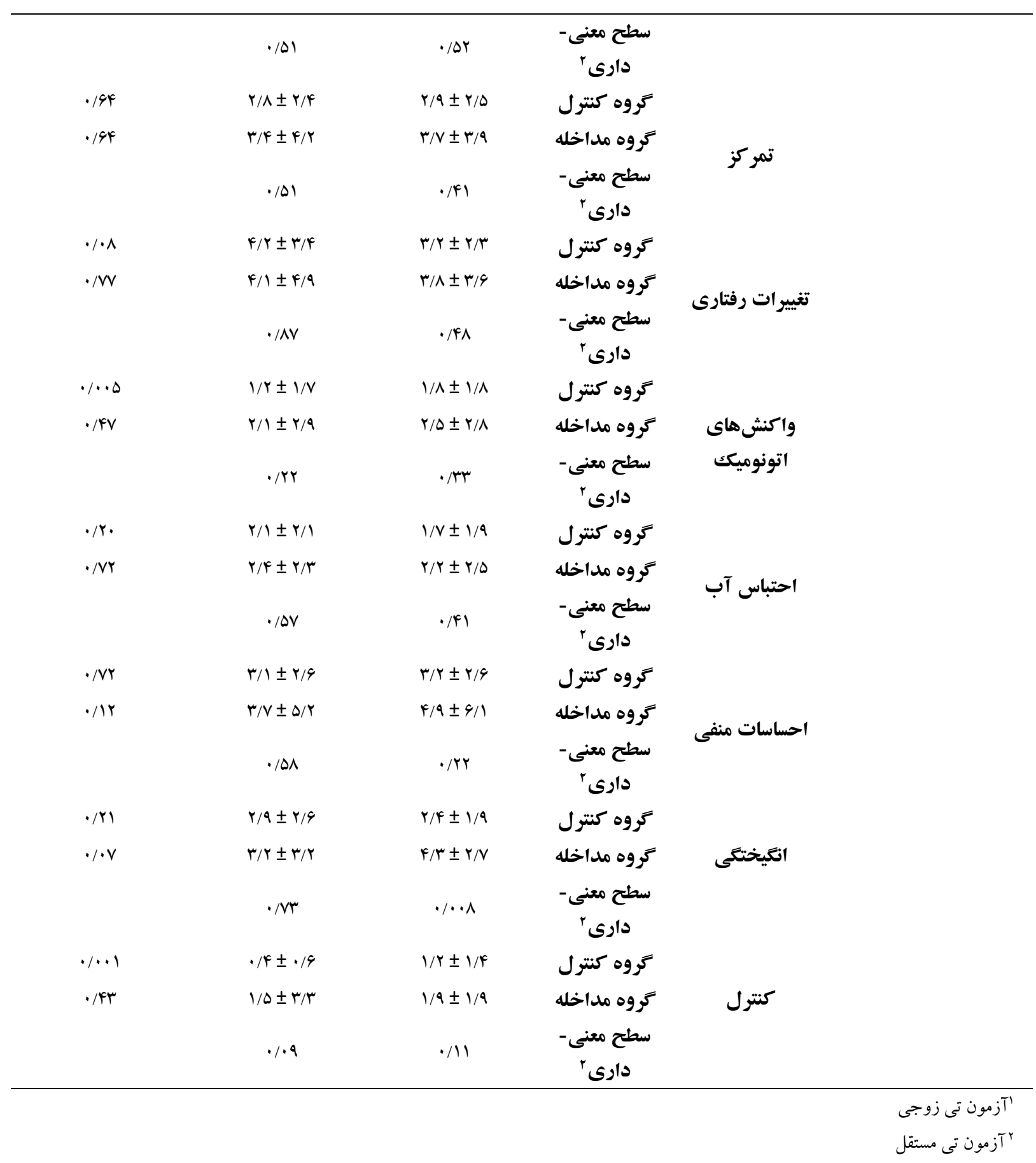

شكل ا: فلوجارت مطالعه و نحوه تخصيص افراد به دو كروه مداخله و كنترل 


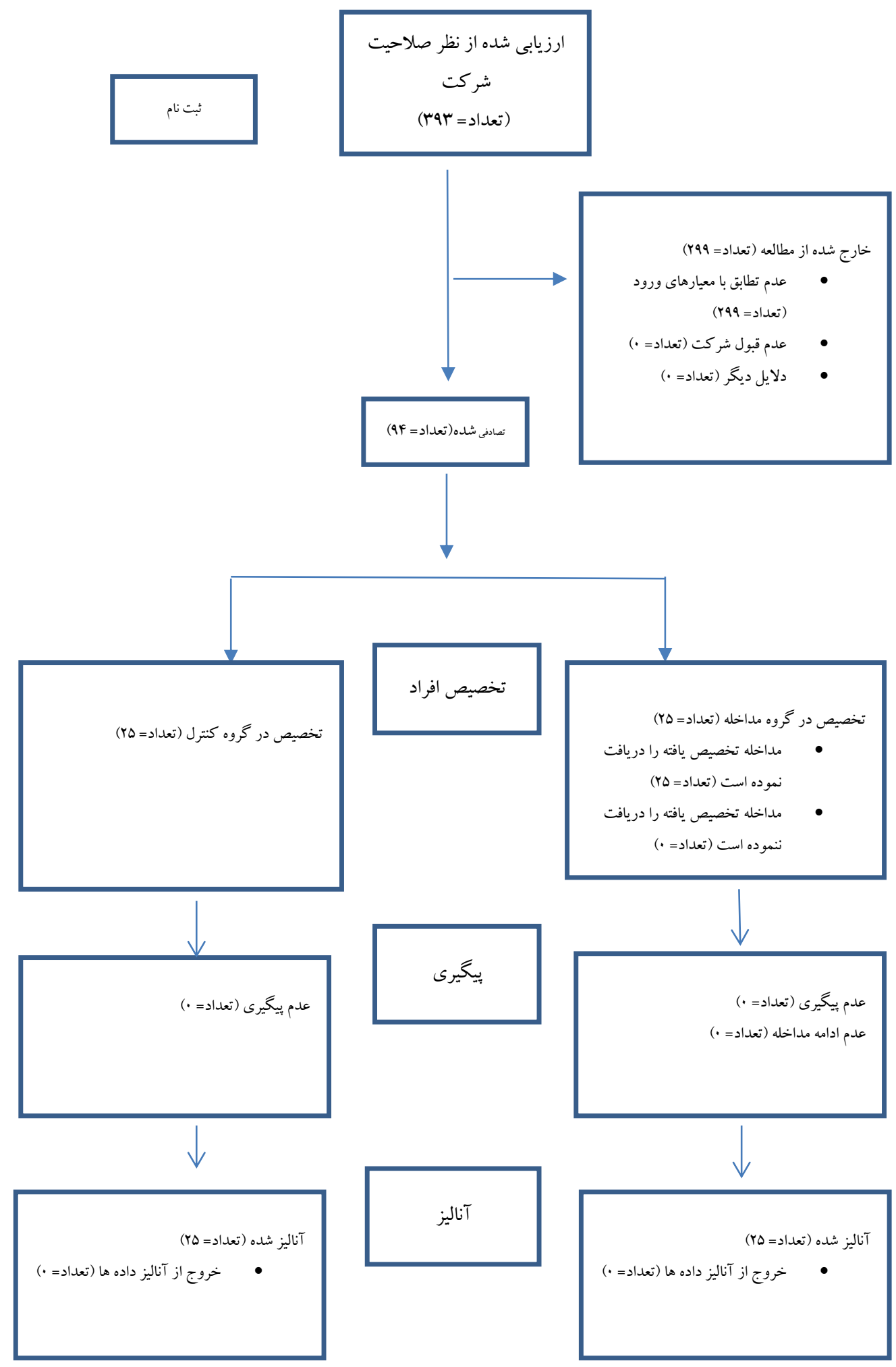

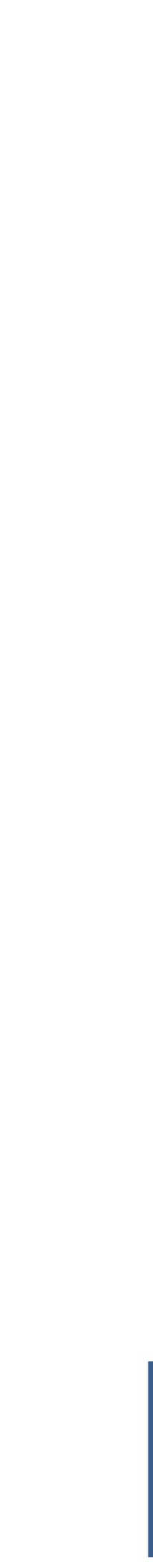

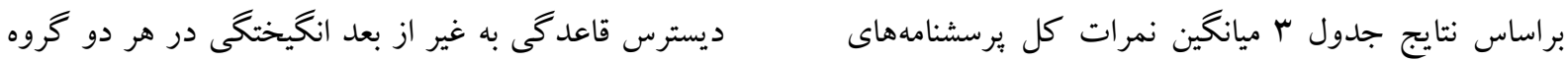
شدت ديسمنوره و ديسترس قاعدگى و نيز همهى ابعاد مداخله و كنترل قبل از مداخله تفاوت معنىدارى نداشت 
يش آزمون يافتها نشان داد كه در متغير شدت ديسمنوره با كنترل كردن ساير عوامل، اختلاف معنىدارى بين دو گروه

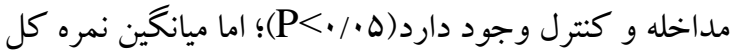
يرسشنامه ديسترس قاعدگى و نيز ابعاد آن، بين دو گروه

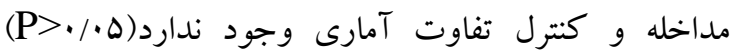

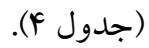

(P>// (P). همجنين بين نمرات كل برسشنامهاى ديسمنوره و ديسترس قاعدگى و نيز ابعاد آن به غير از متغير شدت ديسمنوره بعد از مداخله تفاوت معنىدارى وجود

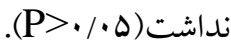

جهت كنترل اثرات متغيرهاى مخدوش كننده از تحليل كوواريانس استفاده شد. به همين منظور ميانخين نمرات

جدول †. آزمون كوواريانس براى مقايسه نمره هيش آزمون و پس آزمون ديسمنوره و ديسترس قاعدكى در دو كروه كنترل و مداخله

\begin{tabular}{|c|c|c|c|c|c|c|}
\hline$P$ value & $\begin{array}{c}\text { آماره آزمون } \\
\text { (F) }\end{array}$ & مجذورانكين & آزادى درجه & مجموع نمرات & & منبع \\
\hline$\cdot 1 \cdots$ & $r q / r$ & $1 r \Delta / r$ & 1 & $1 r \Delta / r$ & بيش آزمون & \\
\hline \multirow[t]{2}{*}{.$/ .1$} & $1 r / v$ & $90 / \pi$ & 1 & $90 / \pi$ & كروه & شدت \\
\hline & & $F / \Lambda$ & pV & YrF/9 & خطا & ديسمنوره \\
\hline$\cdot / \cdots$ & $\wedge \Delta /{ }^{\circ}$ & $11099 / 1$ & 1 & $11099 / 1$ & بيش آزمون & \\
\hline \multirow[t]{2}{*}{$\cdot / F r$} & .194 & $\Delta F / \Delta$ & 1 & $\Lambda F / \Delta$ & كروه & ديسترس \\
\hline & & $1 \pi \Delta / F$ & eV & $9491 / \mathrm{N}$ & خطا & قاعدكى \\
\hline$\cdot / \cdots$ & $r \Delta / q$ & $r 0.19$ & 1 & $r \Delta \cdot / 9$ & بيش آزمون & \\
\hline \multirow[t]{2}{*}{$\cdot N F$} & .11 & $1 / 0$ & 1 & $1 / 0$ & كروه & درد \\
\hline & & $1 \% / 0$ & qV & $9 M 4 / 9$ & خطا & \\
\hline$\cdot / \cdots$ & $9 r / F$ & $r A F / r$ & 1 & $r \Lambda F / r$ & يُش آزمون & \\
\hline \multirow[t]{2}{*}{.$/ 91$} &.$/ .1$ &.$/ . r$ & 1 & $\cdot / \cdot r$ & كروه & تمر كز \\
\hline & & $4 / 1$ & qV & $194 / r$ & خطا & \\
\hline$\cdot / \cdots$ & $F \mid / 1$ & $f \cdot 9 / \pi$ & 1 & $r \cdot 9 / \pi$ & بيش آزمون & \\
\hline \multirow[t]{2}{*}{$\cdot / \mu q$} & $\cdot / N^{F}$ & $V / f$ & 1 & $V / F$ & كروه & تغتييرات \\
\hline & & $9 / 1$ & FV & $490 / 1$ & خطا & رتسرى \\
\hline 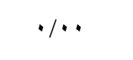 & $r Y / Q$ & $9 . / 1$ & 1 & 9.11 & بيش آزمون & \\
\hline \multirow[t]{2}{*}{.$/ 4 \pi$} & .190 & $r / \Delta$ & 1 & $r / \Delta$ & كروه & واتمنس هاى \\
\hline & & $r / q$ & qV & $\mid A F / \Lambda$ & خطا & الؤوني \\
\hline$\cdot / \cdots$ & $F I / V$ & $11 \% / r$ & 1 & $11 \% / r$ & يشي آزمون & \\
\hline \multirow[t]{2}{*}{.$/ 99$} & $\cdot / \cdot .1$ &.$/ .1$ & 1 &.$/ . .1$ & گروه & احتباس آب \\
\hline & & $r / V$ & qV & IYN/9 & خطا & \\
\hline$\cdot / \cdots$ & $9 N / r$ & $F V \Delta / \Delta$ & 1 & $F V D / \Delta$ & بيش آزمون & \\
\hline \multirow[t]{2}{*}{$\cdot / \Delta F$} & $\cdot / \mu$ & $r / 9$ & 1 & $r / 9$ & كروه & احساس \\
\hline & & $9 / 9$ & ev & $r T V / r$ & خطا & منفى \\
\hline$\cdot / \cdots$ & $1 / r$ & IrY/A & 1 & Irr/A & بيش آزمون & \\
\hline$\cdot / \mathrm{IV}$ & $r Y / \Lambda$ & $11 / r$ & 1 & $11 / r$ & كروه & \\
\hline
\end{tabular}

هجله علمى دانشكاه علوه يِشكى كردستان / دوره بيست و شش / آذر و دى م.ع|| 


\begin{tabular}{|c|c|c|c|c|c|c|}
\hline & $1 / 9$ & $\Delta / \Lambda$ & FV & $r V T / r$ & خطا & \\
\hline$\cdot 1 \cdots$ & $19 / \mathrm{V}$ & $V F / I$ & 1 & $V F / I$ & بيش آزمون & \\
\hline \multirow[t]{2}{*}{ • } &.$/ 9 \mathrm{~V}$ & $F / r$ & 1 & $F / r$ & گروه & كنترل \\
\hline & & $f / f$ & FV & $r \cdot V / q$ & خطا & \\
\hline
\end{tabular}

اشاره كرد، بر اساس اين تئورى تحريك گيرندههاى

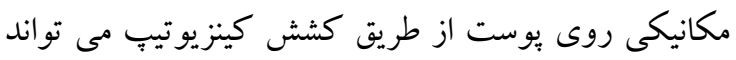

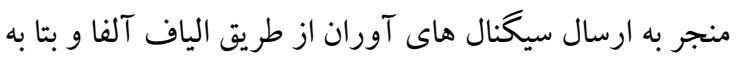
داخل سطوح نخاعى شده و اتصالات جانبى اين مسير روى سينايس هاى مسير انتقال درد موجب مهار بيش سينايِى اين مسيرها و كاهش انتقال سيگنال هاى آوران درد به مراكز ادراكى و متعاقب آن مهار احساس درد مىباشد(.F). از جمله ديخر مكانسيم هاى بيشنهادى براى كاهش ديسمنوره، ثبات

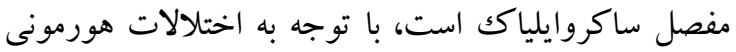
ايجاد شده در دوران قاعدگى و شل شدن ليكامنت هاى ثبات دهنده مفاصل بدن از جمله مفصل ساكروايلياك و با توجه به اينكه ثبات اين مفصل توسط ساختارهاى ليكامنتى تأمين مى دي شود، به نظر مىرسد كه استفاده از اين تكنيك روى نواحى لهى بايين كمر و به خصوص مفاصل ساكروايلياكك مى تواند نقش مؤثرى در ايجاد ثبات اين مفاصل و در نتيجه كاهش درد،

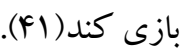
در مطالعه توماس و همكاران كينزيو تيبٍ در دو ناحيه شكم و

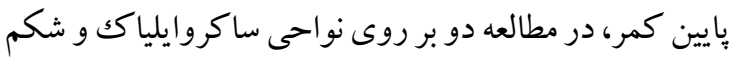
و در مطالعه بختيارى صرفاً در ناحيه كمر الصاق شد، در براحئ صورتى كه در مطالعه حاضر نصب تيب فقط در ناحيه شكم

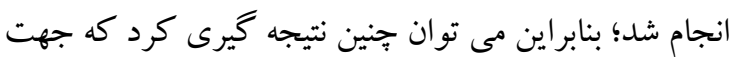

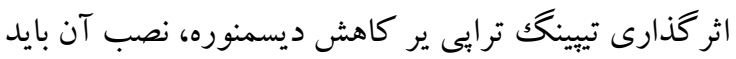

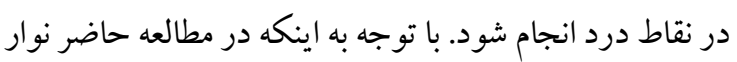

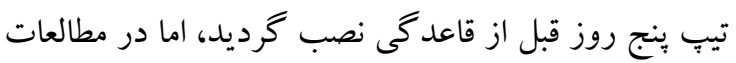

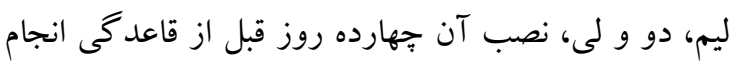

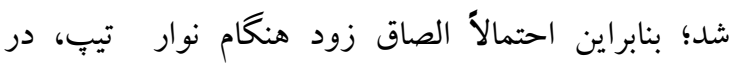

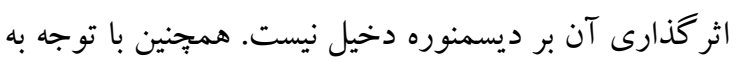
اينكه مدت زمان باقى ماندن تيب در محل در مطالعه لى، جِهار در اين مطالعه تأثير تييينگ ترايى بر شدت ديسمنوره اوليه و سندرم ييش از قاعدگى، بر روى •ها نفر از دانشجويان

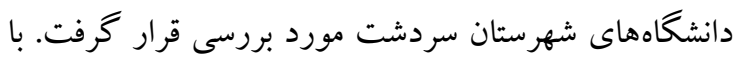
كنترل آمارى متغير مخدوش گر، اين تكنيك توان

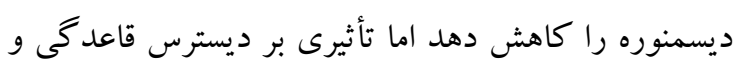

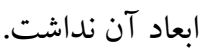
در مقايسه با مطالعه حاضر نتايج ساير مطالعات انجام شده، مورد بررسى قرار گرفت. در بررسى مطالعه ليم و همكاران

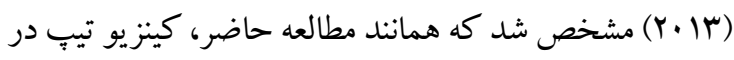

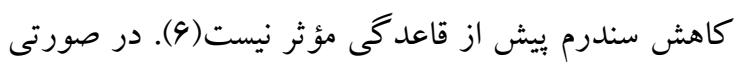
كه ساير محققين از جمله لى (T/.Y)، جوى (Y.|V)

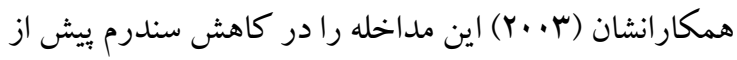

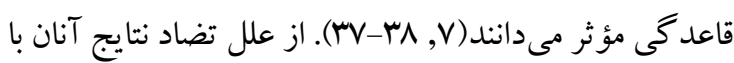
نتايج مطالعه حاضر، مىتوان به زمان انجام مطالعه و عدم

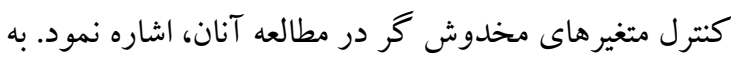
طورى كه در مطالعه لى و دو، تييينك ترايى دو هفته و در

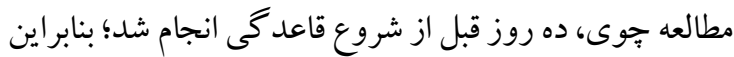
به نظر مى رسد هر جقدر مدت زمان حضور نوار تيّ در فاز لوتئال بيشتر باشد، احتمال تأثير آن نيز بر كاهش ديسترس

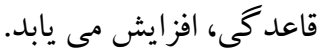
نتايج بررسى مطالعات صورت كرفته در زئه زمينه تأثير

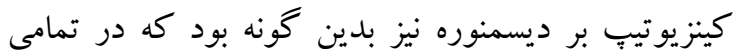
مطالعات انجام شده، مداخله با كينزيو تيب همانند نتايج مطالعه دئه

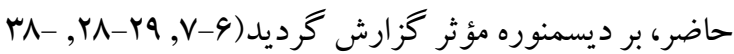

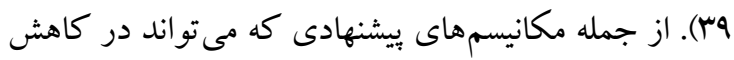
ديسموره كمك كننده باشد، مى توان به تئورى دروازه درد 
كردد نوار تيب جند روز قبل از شروع قاعدگى و به مدت جند سيكل نصب شود. همجنين جه مقدار در محل باقى مانده

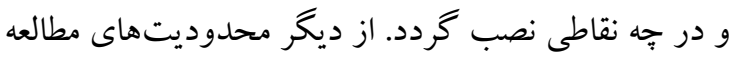
حاضر، تعداد اندكك مطالعات انجام شده در اين زمينه و عدم

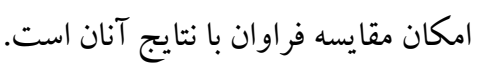

\section{نتيجه كيرى}

نتايج مطالعه حاضر نشان داد كه تكنيك تيبينگك ترابى بر

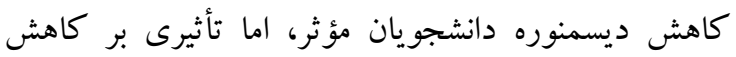
ديسترس قاعدگى نداشت. كنزوتيب يكك روش درمانى غير دارويى است كه داراى اثرات جانبى بسيار كم و و صرفاً

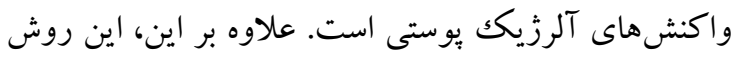
از نظر اقتصادى مقرون به صرفه بوده و حتى نصب آن توسط آرسط

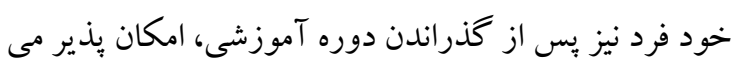

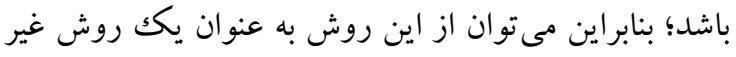
دارويى مؤثر در درمان ديسمنوره استفاده نمود.

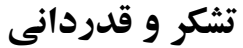

بدين وسيله از تمامى شركت كنند كان در مطالعه تشكر و

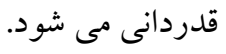

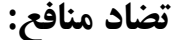

هيج كدام از نويسند گان اين مطالعه، افراد و يا دستكاه ها تعارض منافعى براى انتشار اين مقاله ندارند.

هفته و در مطالعه دو، دو هفته، اما در مطالعه حاضر ده روز بود؛ بنابراين به نظر مى رسد باقى ماندن نوار تيب در محل درد

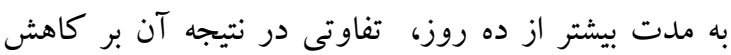
ديسمنوره ايجاد نمى كند. افزايش تعداد سيكل هاى انجام مداخله به بيشتر از دو سيكل نيز به نظر نقشى در تأثير تيبينگ لته

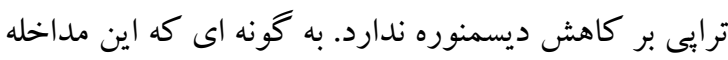

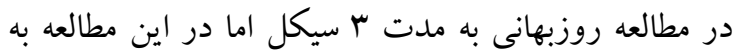

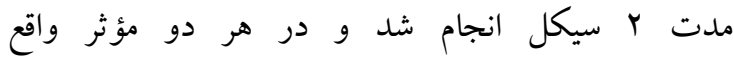

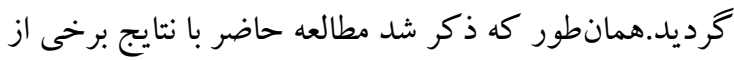
مطالعات همسو بوده و با برخى نيز در تناقض است. با توجه به

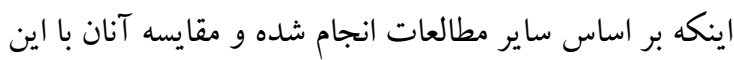

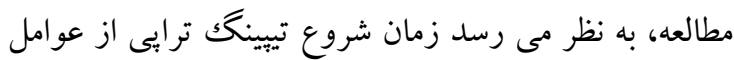
مؤثر بر كاهش ديسترس قاعدگى در مطالعات آنان باشد،

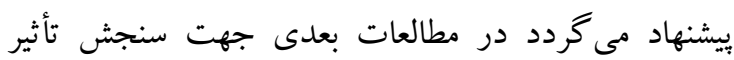

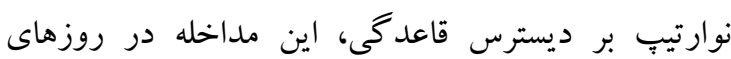
بيشترى از فاز لوتئال، انجام گرد دود. اين مطالعه داراى محدوديتهايى بود. از جمله اينكه جون جامعه مورد مطالعه دختران مجرد بودند، نتايج صرفاً قابل مالي تعميم به اين گروه مىباشد. همجنين ارزيابى تأثير مداخله فقط

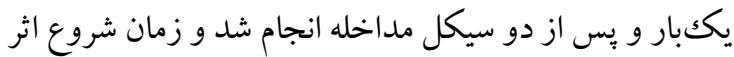
تيب بر ديسمنوره مشخص نشد؛ بنابراين بيشنهاد مى شود در مطالعات بعدى ارزيابى هر فرد در زمانهاى متوالى بّ از

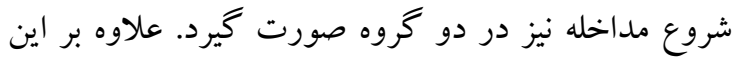

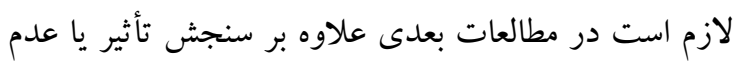

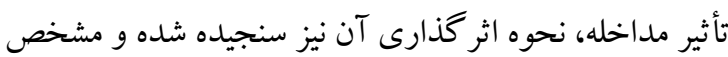

منابع

1.Burkman RT. Berek \& Novak’s gynecology. JAMA. 2012; 308(5):516-7

2.Azagew AW, Kassie DG, Walle TA. Prevalence of primary dysmenorrhea, its intensity, impact and associated factors among female students' at Gondar town preparatory school, Northwest Ethiopia. BMC women's health. 2020; 20(1):1-7.

3.Fernández-Martínez E, Onieva-Zafra MD, Parra-Fernández ML. Lifestyle and prevalence of dysmenorrhea among Spanish female university students. PLoS One. 2018; 13(8):e0201894. 4.Vlachou E, Owens DA, Lavdaniti M, Kalemikerakis J, Evagelou E, Margari N, Fasoi G, Evangelidou E, Govina O, Tsartsalis AN. Prevalence, wellbeing, and symptoms of dysmenorrhea among university nursing students in Greece. Diseases. 2019; 7(1):5. 
5.Kharaghani R, Damghanian M. The prevalence of dysmenorrhea in iran: A systematic review and meta-analysis.

6.Lim C, Park Y, Bae Y. The effect of the kinesio taping and spiral taping on menstrual pain and premenstrual syndrome. JPTS. 2013;25(7):761-4.

7.Lee KO, JuChae H. Effects of the Balance Tapping Therapy on Dysmenorrhea and Premenstrual Syndrome. Indian J Sci Technol. 2016; 9(46).

8.Dorn LD, Negriff S, Huang B, Pabst S, Hillman J, Braverman P, Susman EJ. Menstrual symptoms in adolescent girls: association with smoking, depressive symptoms, and anxiety. JAH. 2009; 44(3):237-43.

9.Hardi G, Evans S, Craigie M. A possible link between dysmenorrhoea and the development of chronic pelvic pain. ANZJOG. 2014; 54(6):593-6.

10.Ye R, Wang S, Li Y, Wu R, Pei J, Wang J, Zhao Z. Primary dysmenorrhea is potentially predictive for initial orthodontic pain in female patients. Angle Orthod. 2014; 84(3):424-9.

11.Latthe P, Latthe M, Say L, Gülmezoglu M, Khan KS. WHO systematic review of prevalence of chronic pelvic pain: a neglected reproductive health morbidity. BMC public health. 2006; 6(1):1-7.

12.Diagnostic APA. statistical manual of mental disorders: DSM-5 (ed.) APA. Washington D. Pub; 2013.

13.Ranjbaran M, Samani RO, Almasi-Hashiani A, Matourypour P, Moini A. Prevalence of premenstrual syndrome in Iran: A systematic review and meta-analysis. IJRM. 2017; 15(11):p 679.

14 .Bakare AT, Panti AA, Yunusa MA, Obembe A. Correlates and self-management strategies of premenstrual dysphoric disorder (PMDD) among nursing students in a Nigerian teaching hospital. IJMMS. 2019; 11(3):20-6.

15. Bertone-Johnson ER, Whitcomb BW, Rich-Edwards JW, Hankinson SE, Manson JE. Premenstrual syndrome and subsequent risk of hypertension in a prospective study. AJE. 2015; 182(12):1000-9.

16.Charu S, Amita R, Sujoy R, Thomas GA. 'Menstrual characteristics' and 'Prevalence and Eff ect of Dysmenorrhea'on Quality of Life of medical student s. IJCRIMPH.2012;4(4):1.

17. Allihabi A. Premenstrual Syndrome-Prevalence, Severity and Effect on Academic Performance: A Comparative Study Between Students of Medicine and Literature. JWHG. 2019;6:1-8.

18. Kitamura M, Takeda T, Koga S, Nagase S, Yaegashi N. Relationship between premenstrual symptoms and dysmenorrhea in Japanese high school students. AWMH. 2012; 15(2):131-3.

19.Parker, M.A., Sneddon, A.E. and Arbon, P., 2010. The menstrual disorder of teenagers (MDOT) study: determining typical menstrual patterns and menstrual disturbance in a large population-based study of Australian teenagers. BJOG, 117(2), pp.185-192.

20 Lee H, Choi TY, Myung CS, Lee MS. Herbal medicine Shaofu Zhuyu decoction for primary dysmenorrhea: a systematic review protocol. Syst. Rev. 2016;5(1):1-7.

21 .Balık G, Üstüner I, Kağıtcı M, Şahin FK. Is there a relationship between mood disorders and dysmenorrhea?. J Pediatr Adolesc Gynecol. 2014; 27(6):371-4.

22 .Lefebvre G, Pinsonneault O, Antao V, Black A, Burnett M, Feldman K, Lea R, Robert M. Primary dysmenorrhea consensus guideline. JOGC. 2005; 27(12):1117-46.

23.Chen CX, Barrett B, Kwekkeboom KL. Efficacy of oral ginger (Zingiber officinale) for dysmenorrhea: a systematic review and meta-analysis. eCAM. 2016; 2016.

24.Yoshida A, Kahanov L. The effect of kinesio taping on lower trunk range of motions. Res Sports Med. 2007; 15(2):103-12.

هبله علمى دانشكاه علوم بِزشكى كردستان / دوره بيست و شش / آذر و دى معاן 
25.Macdonald R. Taping techniques: principles and practice. $2^{\text {nd }}$ ed. London, United Kingdom: Elsevier Health Sciences; 2004.

26. Yum KS, Kang SG, Han HJ. The effect of balance taping for prevention of menstrual pain in female middle school students. JPTS. 2017; 29(5):813-8.

27.Perry M, Judge M, Millar D, McDonald D. An exploratory pilot of factors associated with premenstrual syndrome in minority women. Int. J. Nurs. Sci.. 2015; 2(2):118-22.

28.Tomás-Rodríguez MI, Palazón-Bru A, John DR, Toledo-Marhuenda JV, del Rosario Asensio-García M, Gil-Guillén VF. Effectiveness of medical taping concept in primary dysmenorrhoea: a two-armed randomized trial. Sci. Rep. 2015; 5(1):1-9.

29.Roozbahani RE, Najad RM. A comparison of the effect of stretching exercises and kinesio taping on the primary dysmenorrhea of high school girls. J Arak Uni Med Sci. 2015; 18(97):18.

30.Han CH, Hwang HS, Lee YJ, Lee SN, Abanes JJ, Lee BH. Chronic depression treated successfully with novel taping therapy: a new approach to the treatment of depression. Neuropsychiatr Dis Treat. 2016; 12:1281.

31.Kang SA, Chon MY. Comparative effectiveness of taping therapy versus compression stocking on edema, pain, and fatigue in the lower extremities of hospital nurses. Indian J Sci Technol. 2015; 8:15.

32.Moos RH. The development of a menstrual distress questionnaire. Psychosom. Med.. 1968; 30(6):853-67.

33.Qorbanalipour K, Ghaderi F, Jafarabadi MA, Charandabi SM. Validity and reliability of the Persian version of modified Moos Menstrual Distress Questionnaire. IJOGI. 2016; 19(29):118.

34.Scott J, Huskisson EC. Vertical or horizontal visual analogue scales. ARD 1979; 38(6):560. 35.Kashefi F, Ziyadlou S, FADAEI A, Ashraf AR, Jafari P. The effect of SP6 acupressure on primary dysmenorrhea in medical univesity students in Birjand, 2006-2007.

36.Eriksson K, Wikström L, Årestedt K, Fridlund B, Broström A. Numeric rating scale: patients' perceptions of its use in postoperative pain assessments. Appl Nurs Res. 2014; 27(1):41-6.

37.Choi JH. Effects of kinesio taping and hot packs on premenstrual syndrome in females. JPTS. 2017; 29(9):1514-7.

38.Park KM, Lee SH, Do ES. A study on the effects of the kinesio tape method on perimenstrual discomforts. JKACHN. 2003; 14(3):415-23.

39.Bakhtiari A AA, Akbarzadeh Z, Sheikhian Azizi S. effects of kinesio tape on pain and disfunctional disability on young women with menstrual low back pain. koomesh. 2014; 41(14):821-8.

40.Nosaka K. The effect of kinesio taping® on muscular micro-damage following eccentric exercises. In15th Annual Kinesio Taping International Symposium Review 1999 (pp. 70-73). Kinesio Taping Association Tokyo.

41. Levangie PK, Norkin CC. Joint structure and function: a comprehensive analysis. 2011. 